J. Clin. Chem. Clin. Biochem.

Vol. 16, 1978, pp. $381-385$

\title{
Development of a Radioimmunoassay for Pig Pancreatic Kallikrein
}

\author{
By E. Fink and Christine Güttel
}

Aus der Abteilung für Klinische Chemie und Klinische Biochemie (Leitung: Prof. Dr. H. Fritz) in der Chirurgischen Klinik der Universität München

(Received November 11, 1977)

Summary: A radioimmunoassay for the determination of pig pancreatic kallikrein was developed. The chloramine-T method was employed for the labelling of the antigen with ${ }^{125}$ I. The assay allows the determination of kallikrein in concentrations as low as $0.4 \mu \mathrm{g} / \mathrm{l}$. Pig urinary and pig submandibular kallikreins are indistinguishable from pig pancreatic kallikrein by the assay. No cross reactivity was observed for bovine trypsin and chymotrypsin, porcine trypsin and kallikreins of guinea pig submandibular glands and guinea pig coagulation glands. Because of the high specificity of the assay, which is not attainable with conventional assays based on the enzymatic activity, the radioimmunoassay is highly suited for investigations into the physiological role and the pharmacological mechanism of action of pig glandular kallikreins.

\section{Entwicklung eines Radioimmunoassays für Kallikrein aus Schweinepankreas}

Zusammenfassung: Für die Bestimmung von Schweinepankreaskallikrein wurde ein Radioimmunoassay entwickelt. Die Markierung des Antigens mit ${ }^{125} \mathrm{~J}$ erfolgte nach der Chloramin-T-Methode. Der Radioimmunoassay gestattet die Bestimmung von Kallikrein in Konzentrationen bis herab zu 0,4 $\mu \mathrm{g} / 1$. Kallikreine aus Schweineharn und Schweinesubmandibularisdrüsen sind im Radioimmunoassay nicht von Schweinepankreaskallikrein zu unterscheiden. Keinerlei Kreuzreaktion wurde für Trypsin (Rind, Schwein), Chymotrypsin (Rind) und Kallikreine aus Submandibularisdrüsen und Koagulationsdrüsen von Meerschweinchen gefunden. Auf Grund der hohen Spezifität der Bestimmungsmethode, die mit konventionellen, auf der enzymatischen Aktivität berihenden Methoden nicht erreicht wird, ist der Radioimmunoassay bestens geeignet für Untersuchungen über die physiologische Funktion und den pharmakologischen Wirkungsmechanismus von Schweinepankreaskallikrein.

\section{Introduction}

The determination of kallikrein is usually achieved by measuring the rate of hydrolysis either of synthetic substrates or of the natural substrate kininogen $(1-3)$. These assays are not specific for kallikrein, because they also detect other proteases. For studies on the physiological function and the pharmacological mechanism of action of kallikrein, which include the measurement of the enzyme in tissues and body fluids, a more specific assay is required. This requirement is met by the radioimmunoassay technique, which is based on the competitive inhibition of the binding of labelled antigen to its specific antibody by the unknown or by the unlabelled antigen used as a standard.

By employing this method an assay was developed, with a sensitivity (lower detection limit 40-300 pg) as high as that of the most sensitive enzymatic assays (1).
The radioimmunoassay is specific for pig kallikreins of pancreas, urine and submandibular gland. All other proteinases investigated so far do not interfere in the assay.

\section{Materials and Methods}

Pig pancreatic kallikrein used for radioiodination and as a standard in the radioimmunoassay was a highly purified neuraminidase-treated preparation (3) kindly provided by Dr. F. Fiedler, Munich. Pig trypsin, Merck, Cat. No. 8350; cristalline bovine trypsin, Novo Industri; guinea pig coagulation gland kallikrein and guinea pig submandibular kallikrein were gifts from Dr. C. Moriwaki, Tokyo and Dr. M. Lemon, Bristol. Pig urinary kallikrein and pig submandibular kallikrein preparations were isolated as described $(4,5)$. Rabbit anti-kallikrein serum was a gift of Bayer AG, Wuppertal; donkey anti-rabbit IgG serum was purchased from Wellcome Company, Cat, No. RD 17. 


\section{Buffers}

Buffer A: $0.015 \mathrm{~mol} / 1 \mathrm{NaH}_{2} \mathrm{PO}_{4}, 0.15 \mathrm{~mol} / 1 \mathrm{NaCl}, 200 \mathrm{mg}$ Merthiolate, $2 \mathrm{~g} / 1$ bovine serum albumin, $0.01 \mathrm{~mol} / 1$ EDTA, pH 7.4;

Buffer B: $0.015 \mathrm{~mol} / 1 \mathrm{NaH}_{2} \mathrm{PO}_{4}, 0.15 \mathrm{~mol} / 1 \mathrm{NaCl}, 200 \mathrm{mg} / 1$ Merthiolate, $40 \mathrm{~g} / 1$ bovine serum albumin, $\mathrm{pH} 7.4$; Buffer C: $0.015 \mathrm{~mol} / 1 \mathrm{NaH}_{2} \mathrm{PO}_{4}, 0.15 \mathrm{~mol} / 1 \mathrm{NaCl}, \mathrm{pH} 7.4$.

\section{Radioiodination}

The modification of the chloramine T method of Greenwood \& Hunter (6) described by Erhardt et al. (7) was used for the radioiodination of kallikrein. All reagents were dissolved in buffer $\mathrm{C}$. The reaction was started by adding $10 \mu \mathrm{l}(18.5 \mathrm{MBq}=$ $0.5 \mathrm{mCi}) \mathrm{Na}^{125} \mathrm{I}$ and $10 \mu \mathrm{l}(30 \mu \mathrm{g})$ chloramine-T to $5 \mu \mathrm{l}(2.5 \mu \mathrm{g})$ kallikrein solution. After 5-10 s of mixing the reaction was stopped by $20 \mu \mathrm{l}(60 \mu \mathrm{g})$ sodium metabisulfite. The reaction mixture was then transferred to a Sephadex G-75 column $1.2 \times 14 \mathrm{~cm}$, the reaction vial was washed once with $50 \mu \mathrm{l}$ of a $10 \mathrm{~g} / 1$ potassium iodide solution. The column was eluted with buffer $C(40 \mathrm{ml} / \mathrm{h})$, and $0.8 \mathrm{ml}$ fractions were collected into disposable polypropylene tubes containing $50 \mu \mathrm{l}$ of buffer B. The radioactivity of the fractions was determined and the 4-6 fractions with the highest radioactivity of the peak corresponding to the elution volume of kallikrein were pooled and diluted with buffer $A$ to a concentration of 250000 counts/min $\cdot \mathrm{ml}$ for use in the radioimmunoassay.

\section{Radioimmunoassay conditions}

Dilutions of kallikrein standard samples, unknowns, anti-rabbit IgG serum and ${ }^{125}$ Ikallikrein were prepared with buffer $A$. $70 \mathrm{mg} / \mathrm{l}$ of rabbit IgG were added to the ${ }^{125}$ I-kallikrein solution Antikallikrein serum was diluted with buffer $B$ so as to give a binding fraction of $0.50^{125} \mathrm{I}$ kallikrein under the conditions employed in the radioimmunoassay.

The incubation mixtures were set up in disposable polypropylene tubes following the scheme given in table 1 . After an incubation period of 24-48 h, $0.1 \mathrm{ml}$ of the solution of anti-rabbit IgG serum (diluted according the recommendation of the manufacturer) was added. After another $2-3 \mathrm{~h}, 0.5 \mathrm{ml}$ buffer $A$ were added. After $10 \mathrm{~min}$ centrifugation at $6000 \mathrm{~g}$ the supernatant was removed by aspiration and the radioactivities of the precipitates were measured in a gamma counter. All calibration samples were set up in quadruplicate.

Standard curves were obtained by plotting the fraction of bound radioactivity, $\frac{B-N}{B_{o}-N}$ (B: counts bound, $B_{0}$ : counts read for zero dose, $\mathrm{N}$ : nonspecifically bound counts), against ng kallikrein in a linear-log mode. The assays were evaluated by means of a computer employing the spline approximation method $(8-10)$.

\section{Specificity}

The immunological reactivity of antikallikrein serum with other proteases was checked by employing, per incubation tube, $10 \mathrm{ng}$ $-100 \mu \mathrm{g}$ of bovine trypsin, bovine chymotrypsin, or porcine trypsin; $0.1 \mathrm{ng}-10 \mu \mathrm{g}$ of kallikreins from guinea pig submandibular and coagulation glands; and approximately $0.1-10 \mathrm{ng}$ of pig submandibular and pig urinary kallikrein.

Tab. 1. Preparation of radioimmunoassay incubation mixtures

The amounts of the solutions pipetted into polypropylene disposable tubes are shown in the table.

\begin{tabular}{|c|c|c|c|c|c|}
\hline . & Buffer A & Buffer B & Sample $\left.{ }^{1}\right)$ & $\begin{array}{l}\text { Anti- } \\
\text { kallikrein } \\
\text { serum }\end{array}$ & $\begin{array}{l}{ }^{125} \text { I-kalli- } \\
\text { krein }\end{array}$ \\
\hline & $\mu \mathrm{l}$ & $\mu 1$ & $\mu l$ & $\mu \mathrm{l}$ & $\mu \mathrm{l}$ \\
\hline $\mathbf{N}$ & 200 & 100 & - & - & 100 \\
\hline & 200 & - & - & 100 & 100 \\
\hline Samples & 100 & - & 100 & 100 & 100 \\
\hline
\end{tabular}

1) Standard or unknowns

\section{Results}

\section{Properties of ${ }^{125}$ I-labelled kallikrein}

The chloramine-T method $(6,7)$ was employed for the iodination of kallikrein. The reaction mixture was immediately subjected to gel filtration which effectively separated the labelled kallikrein from unreacted $\mathrm{Na}^{125} \mathrm{I}$ (fig. 1). In one experiment the immunological reactivity of the fractions of the ${ }^{125}$ I-kallikrein peak was checked by setting up titration curves for each fraction. Except for the first fraction of the peak, with a maximum binding of 0.28 , no significant differences in the maximum binding ( 0.82 for all other fractions) and in the slopes of the curves were observed. Therefore, for use in the radioimmunoassay, usually the 4-6 fractions representing the maximum of the ${ }^{125}$ I kallikrein peak (fractions 11-15 in fig. 1) were pooled. The specific radioactivity of the ${ }^{125} \mathrm{I}$-kallikrein preparations, calculated from the radioactivity eluted in the kallikrein peak, was $1.11-4.8 \mathrm{MBq} / \mu \mathrm{g}(30-130 \mu \mathrm{Ci} / \mu \mathrm{g})$, the mean value \pm standard deviation of 21 iodinations was $2.85 \pm$ $0.93 \mathrm{MBq} / \mu \mathrm{g}(77 \pm 25 \mu \mathrm{Ci} / \mu \mathrm{g})$.

The ${ }^{125}$ I-labelled kallikrein was used in the radioimmunoassay for up to five weeks. During this time the fraction of radioactivity precipitable with an equal volume of $100 \mathrm{~g} / 1$ trichloroacetic acid decreases from 0.98 to about 0.80 .

Figure 2 shows a typical titration curve. The maximum binding of $21{ }^{125} \mathrm{I}$-kallikrein preparations varied between 0.38 and $0.86(0.68 \pm 0.14$, mean \pm S.D. $)$. Only preparations with a maximum binding higher than 0.50 (20 out of 21 preparations) were used in the radioimmunoassay.

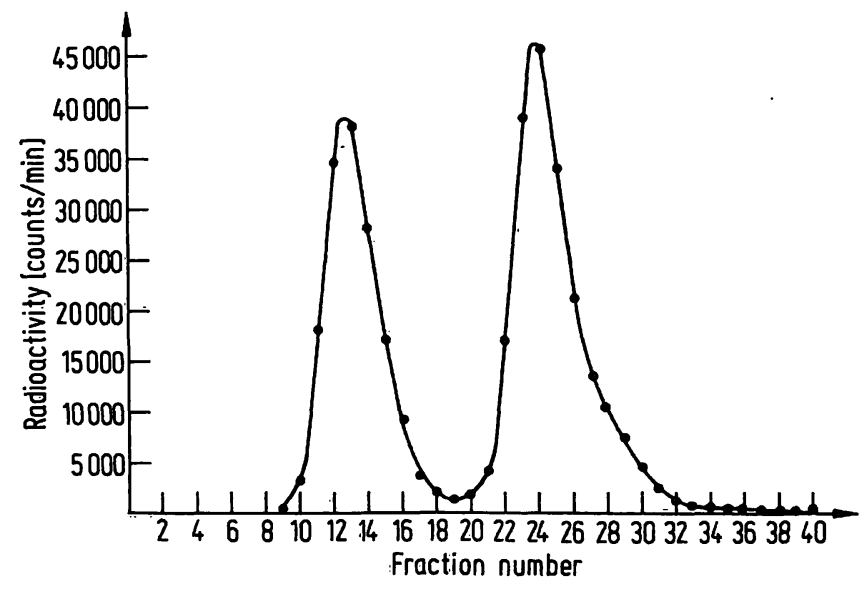

Fig. 1. Separation of ${ }^{125}$ I labelled pig pancreatic kallikrein (fractions 9-19) from unreacted $\mathrm{Na}{ }^{125} \mathrm{I}$ on a Sephadex G 75 column $(1.2 \times 14 \mathrm{~cm})$.

Fraction volume: $0.8 \mathrm{ml}$, elution buffer: buffer $C$. The radioactivity of the fractions was measured with geometry adjusted to low counting efficiency. In this experiment fractions $11-15$ were pooled for use in the radioimmunoassay. 


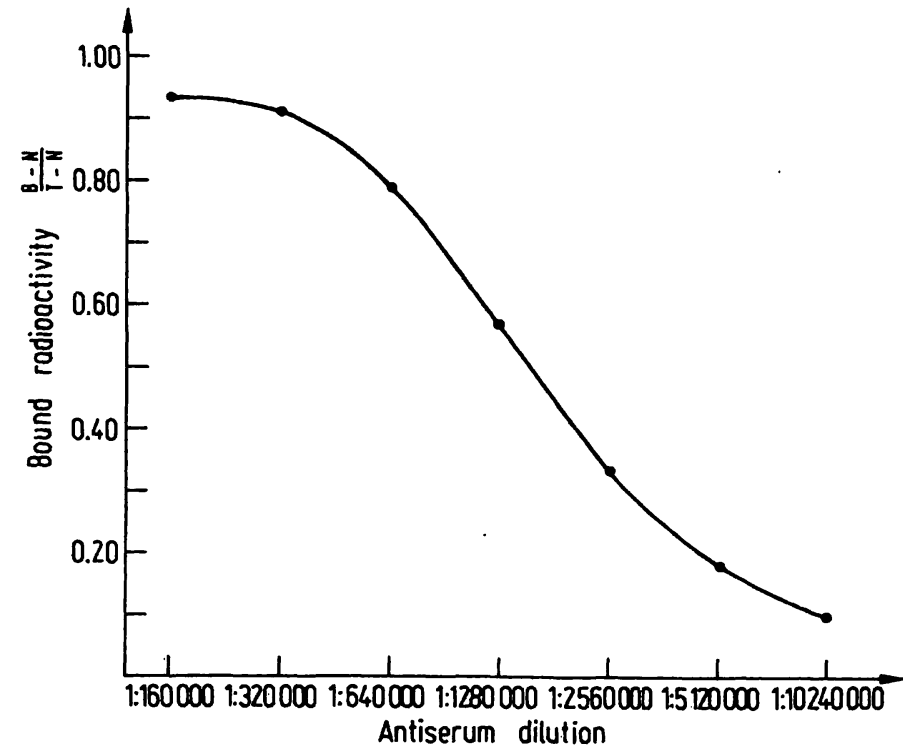

Fig. 2. Antiserum titration curve.

The tubes, containing $200 \mu \mathrm{l}$ buffer B, $100 \mu l$ anti-kallikrein serum dilution and $100 \mu{ }^{125} \mathrm{I}-\mathrm{kallikrein}$ (28000 counts/min) were held at room temperature for 2 days. Bound ${ }^{125} I-k a l l i k r e i n$ was precipitated by the addition of $100 \mu l$ of second antibody dilution. The antiserum dilutions given in the figure are the final dilutions in the incubation mixture.

Kinetics of the binding of ${ }^{125}$ I-kallikrein to the antibody In order to find the optimal incubation conditions for the routine radioimmunoassay the kinetics of the binding of ${ }^{125}$ I-kallikrein to the antibody was studied at 8,22 and $37^{\circ} \mathrm{C}$. Figure 3 summarizes the results. The lowest binding rate is observed at $8^{\circ} \mathrm{C}$ and, as indicated by the shape of the curve, the endpoint is not yet reached after $120 \mathrm{~h}$. Both at 25 and $37^{\circ} \mathrm{C}$ equilibrium is reached between 48 and $72 \mathrm{~h}$; maximum binding at $37^{\circ} \mathrm{C}$ is significantly lower than at $25^{\circ} \mathrm{C}$.

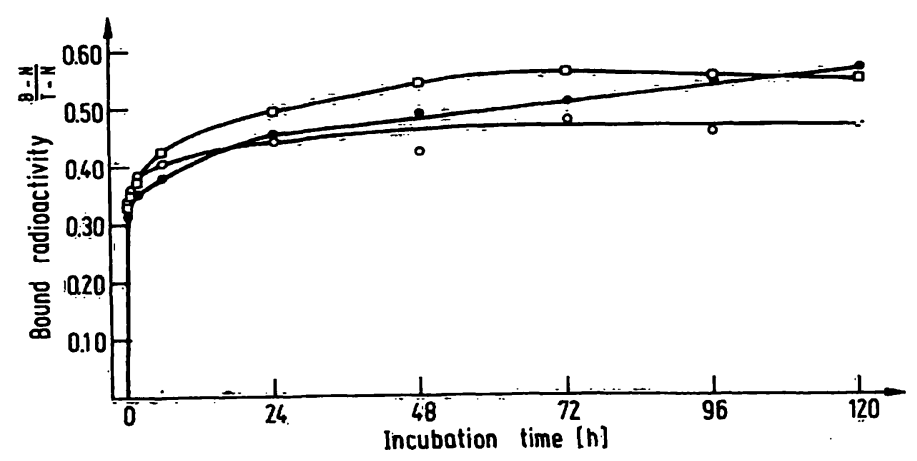

Fig. 3. Time and temperature-dependence of the binding of 125 I-kallikrein to an tibody. Incubation mix tures correspond to $\mathrm{B}_{0}$ and $\mathrm{N}$ in Table 1 . The samples were held at $8^{\circ} \mathrm{C} \bullet-, 25^{\circ} \mathrm{C}$ 口- 0 and $37^{\circ} \mathrm{Co-O}$. The incubation was stopped by freezing the samples at $-78^{\circ} \mathrm{C}$. The frozen samples were stored at $-21^{\circ} \mathrm{C}$. All samples were thawed simultaneously at $30{ }^{\circ} \mathrm{C}$ for 3 min and the second antibody was added to precipitate the bound ${ }^{125}$ I-kallikrein.

\section{Precision}

Both intraassay and interassay precision are dependent on the concentration of kallikrein in the sample. In the range of 0.3 to $5 \mathrm{ng}$ per incubation mixture the coefficient of variation for quadruplicates is generally $6-10 \%$. For the interassay precision the coefficient of variation for the same concentration range calculated from 6 consecutive assays was $6-15 \%$.

\section{Sensitivity}

The lower detection limit is generally between 0.4 and $3.0 \mu \mathrm{g} / \mathrm{l}$ sample volume, depending on the quality of the labelled kallikrein and the incubation conditions (fig. 4).

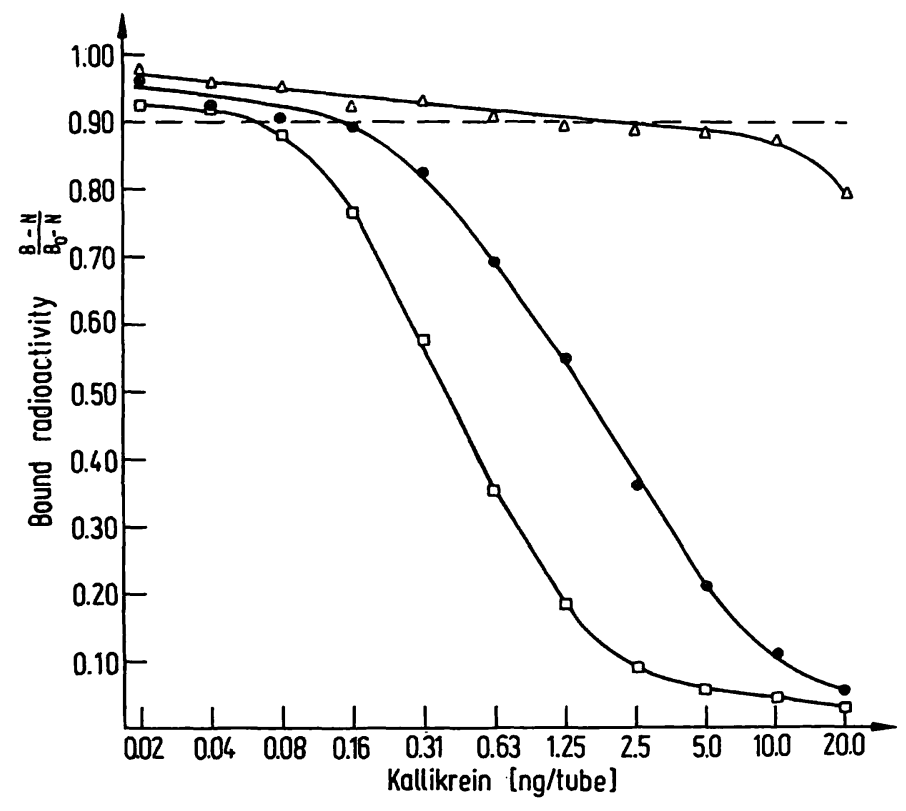

Fig. 4. Influence of preincubation on standard curves. Reagents were used as summarized in Table 1. Incubation conditions:

A: preincubation of tracer and anti-kallikrein serum for $42 \mathrm{~h}$ followed by $24 \mathrm{~h}$ after addition of standard $(\Delta-\Delta)$;

B: incubation of standard, anti-kallikrein serum and tracer for $42 \mathrm{~h}(\bullet-\bullet)$;

C: preincubation of standard and anti-kallikrein serum for $42 \mathrm{~h}$ followed by $24 \mathrm{~h}$ after addition of tracer. ---0.90 intercept defined as lower detection limit.

\section{Specificity}

In order to test the specificity of the antiserum several serine proteases were evaluated with respect to their capacity to inhibit competitively the binding of ${ }^{125} \mathrm{I}$ kallikrein. Absolutely no cross reactivity was observed for bovine trypsin and chymotrypsin, porcine trypsin and guinea pig coagulation gland and submandibular gland kallikrein applied in the concentrations described above. The kallikreins of pig urine and pig submandibular glands showed immunological reactivities (nearly) identical to pig pancreatic kallikrein (fig. 5). 


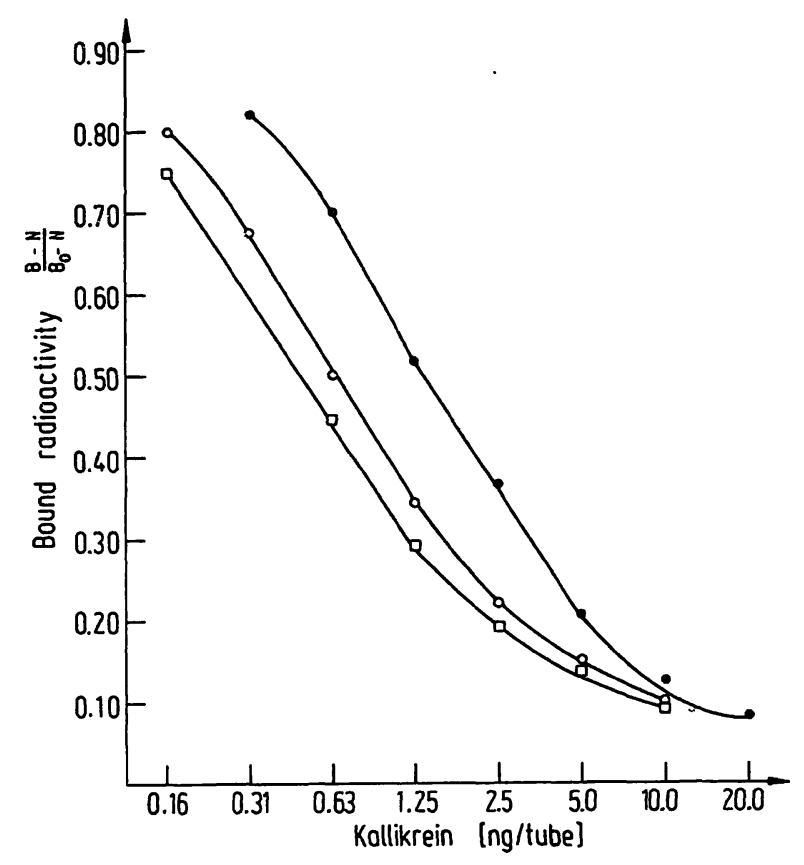

Fig. 5. Cross reactivity of pig urinary kallikrein (o- 0 ) and pig submandibular kallikrein $(\square-\square)$ in the radioimmuno-

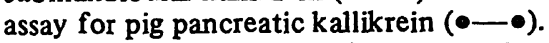

The exact concentration of urinary and submandibular kallikreins was not known.

\section{Discussion}

The chloramine-T method (6,7), widely used for the iodination of proteins, was successfully applied to produce ${ }^{125}$ I-labelled pig pancreatic kallikrein. The iodinated protein is stable, immunologically active and of sufficiently high specific radioactivity for setting up a sensitive radioimmunoassay. The stability of the iodinated kallikrein was checked by determining the amount of radioactivity bound to high molecular weight protein: in four week old preparations a fraction of 0.8 of the radioactivity was still precipitable by trichloroacetic acid.

The immunological reactivity of kallikrein is not seriously effected by the labelling procedure. If a constant amount of freshly prepared ${ }^{125}$ I-kallikrein is incubated with a series of antiserum dilutions (fig. 2), the maximum binding is usually higher than 0.80 ; it decreases for older preparations owing to the release of low molecular weight radioactive substances, which are not bound by the antibody. If these radioactive low molecular weight fragments are removed by gel filtration almost the same maximum binding is observed as for fresh preparations. Nevertheless, the ${ }^{\mathbf{1 2 5}} \mathrm{I}$-kallikrein, is not generally used for longer than five weeks, because the sensitivity of the assay decreases with the age of the preparation.

The results of the kinetic studies (fig. 3) of the binding of ${ }^{125} \mathrm{I}$-kallikrein to the antibody at 8,25 and $37^{\circ} \mathrm{C}$ show that incubation at room temperature $\left(20-25^{\circ} \mathrm{C}\right)$ is preferable for the radioimmunoassay. At low temper- atures the reaction is relatively slow, whereas at higher temperatures the equilibrium is more in favour of dissociation. We routinely incubate the samples at room temperature for $36-48 \mathrm{~h}$. Under these conditions the binding is close to equilibrium. In earlier experiments we had observed a significant decrease of binding for incubation periods longer than $72 \mathrm{~h}$ at all three temperatures investigated (11). We interpreted this effect as a loss of immunological reactivity of the ${ }^{125}$ I-kallikrein and/or the antibody. Since, in our recent experiments, we used the same antiserum but a different ${ }^{125}$ I-kallikrein preparation and did not observe a significant decrease of binding, it seems likely that properties of the ${ }^{125}$ I-kallikrein and not of the antiserum were responsible for this effect.

The sensitivity of radioimmunoassays can be increased by preincubating unlabelled antigen with the antibody before the labelled antigen is added. This technique can also be employed successfully in the kallikrein radioimmunoassay. As figure 4 demonstrates, preincubation for 42 hours before addition of the labelled antigen causes a shift of the standard curve toward lower kallikrein concentrations and an increase of the slope. The lower detection limit is reduced to one half in figure 4 (with the 0.90 intercept defined as the lower detection limit). In other experiments it was reduced occasionally even to one fourth. For most of our investigations this increased sensitivity is not required and, because the total incubation time would be three instead of two days, we do not apply the preincubation method routinely.

The specificity of the test was examined by employing a variety of serine proteases in the radioimmunoassay. Because of the structural homology of pig pancreatic kallikrein with other serine proteases (3) immunological cross reactivity seems possible. However, it turned out that only the kallikreins of pig submandibular gland and pig urine show cross reactivity. No cross reactivity at all was observed for bovine trypsin and chymotrypsin; porcine trypsin and kallikreins of guinea pig submandibular glands and guinea pig coagulation glands. The (nearly) identical slope of the dose response curves (fig. 5) indicates a high similarity if not identity of the three porcine kallikreins in their immunological properties. With the antiserum we use it is impossible to discriminate between the three enzymes by means of the radioimmunoassay. This finding is in agreement with results found by immunodiffusion and immunoelectrophoretic studies (12). Identical precipitation patterns were obtained by the authors using the double diffusion technique of Ouchterlony, when the three kallikreins were allowed to diffuse against purified rabbit IgG directed against any one of the kallikreins. In the immunoelectrophoretic studies different electrophoretic mobilities of the various kallikreins were observed but immunological identity was indicated by the form, location and confluence of the precipitin lines. 
Immunological similarity has also been demonstrated by Geiger \& Mann (13) and Ole-Moiyoi et al. (14) for human saliva, pancreatic and urinary kallikreins using antibodies directed against human urinary kallikrein and human pancreatic extract, respectively.

The radioimmunoassay for pig pancreatic kallikrein was developed with the aim of applying it in studies on the pharmacological effects and the physiological role of this enzyme. Both high specificity and sensitivity are prerequisites for an assay to be used in such studies, since body fluids and tissues have to be examined which might also contain other proteases. The radioimmunoassay presented here is specific for pig glandular kallikreins. However, a discrimination of the different pig glandular kallikreins is not possible. This may cause difficulties in some physiological studies where such a discrimination might be desirable. It seems to us to be impossible to solve this problem, as long as the differences between the glandular kallikreins are not fully understood (12). For studies on the effects of pig pancreatic kallikrein in animals other than the pig, we expect from our investigations that the problem of cross reacting substances will not arise. Some pharmacological studies on the effects of kallikrein on dogs after parenteral application are already published (11).

\section{Acknowledgments}

This work was generously supported by a grant of the Deutsche Forschungsgemeinschaft.

I am very grateful to Prof. $P$. C. Scriba for the kind permission to use the facilities of his laboratory for radioactive work.

I am indebted to Dr. F. Erhardt for his helpful discussions. I wish to thank very much Prof. H. Fritz for his stimulating discussions and comments.

\section{References}

1. Trautschold, I. (1970), in Handbook of Experimental Pharmacology, (Erdös, E. G. \& Wilde, A. F., eds.) Springer Verlag, Berlin, Vol 25, 52-81.

2. Webster, M. E. \& Prado, E. S. (1970) Methods Enzymol. 19, 681-699.

3. Fiedler, F. (1976) Methods Enzymol. 45, 289-303.

4. Tschesche, H., Mair, G., Förg-Brey, B. \& Fritz, H. (1976), Adv. Exp. Med. Biol. 70, 119-122.

5. Lemon, M., Förg-Brey, B. \& Fritz, H. (1976), Adv. Exp. Med. Biol. 70, 209-216.

6. Greenwood, F. C., Hunter, W. M. \& Glover, J. (1963), Biochem. J. 89, 114-123.

7. Erhardt, F., Marschner, I., Pickardt, R. C. \& Scriba, P. C. (1973), Z. Klin. Chem. Klin. Biochem. 11, 381-387.
8. Reinsch, C. H. (1967), Numer. Math. 10, 77.

9. Reinsch, C. H. (1971), Numer. Math. 16, 451.

10. Marschner, I., Erhardt, F. \& Scriba, P. C. (1974), in Radioimmunoassay and Related Procedures in Medicine Vol I, 111-122, International Atomic Energy Agency, Vienna.

11. Fink, E. (1977) in Kininogenases IV, Kallikrein, (Haberland, G. L., Rohen, J. W. \& Suzuki, T., Eds.) Schattauer Verlag, Stuttgart (in press).

12. Fritz, H., Fiedler, F., Dietl, T. \& Warwas, M. (1977) in 1.c. (11).

13. Geiger, R. \& Mann, K. (1977) in 1.c. (11).

14. Ole-Moiyoi, O., Spragg, J., Halbert, S. P. \& Austen, K. F. (1977), J. Immunol. 118, 667-672.

Dr. Edwin Fink

Abteilung für Klinische Chemie und Klinische Biochemie in der Chirurgischen Klinik der Universität München Nußbaumstraße 20

D-8000 München 2 
